\title{
Optimizing the Counselors' Role in Senior High School and Higher Education
}

\author{
Daharnis $^{a}$, Zadrian Ardi ${ }^{\text {a }}$ \\ ${ }^{a}$ Guidance and Counseling Departement Universitas Negeri Padang, Padang, Indonesia \\ Corresponding e-mail: daharnis@konselor.org
}

\begin{abstract}
Many cases in students whose career interests that unsuitable with their majoring, this issues resulting in student activity, learning outcomes, and success; There are also the students want to move their majors even though already in the final semesters. The case are caused by various factors, such as the process of choosing majors, completeness and clarity of information about majors, the role of various parties in helping students choose the right majors in college. This cases and phenomenon are part of the research (2016) on the majoring selection in higher education and the role of counselors in high school with a total sample of 428 students. This research using descriptive analysis method and DZ-MCI inventory. The role of counselors and other related parties in high school and higher education in prevention of incompatibility issues and career goals of students with their majors are discussed.
\end{abstract}

Keywords: majoring choices, optimizing, counselors' role, higher education.

\section{INTRODUCTION}

Many cases in students whose career interests do not match with department they occupy. From the experience and research results, found more than $30 \%$ of students feel unsuited [1]. This can result in the activity, learning outcomes, and overall successes of the students even there also want to move majors despite being in the final semester. On the other hand, a university is required to lead to the improvement of quality and achievement of gold generation in 2045 , Strategic Plan of the Ministry of Technology and Higher Education, Indonesia National Qualification Framework, and Law No. 12 of 2012 [2]-[4]; Or there is a term that high education should achieve tri success [5] that is social success, academic and career, as well as successful personal life [6].

Achieving the direction and purpose of higher education requires various efforts, there are; improvement of learning in such a way that is supported by various factors supporting the success of student learning. From various researches found the factors that influence the success of learning is learning activities [7]-[10]. Students' learning activities are influenced by the interest of students in the occupied department [7], [11]-[21].

The interest of students in learning is related to the suitability of the students with the department they occupy; Whether or not the student with the department he/she occupies is related to the election process at the time of choosing the department to be occupied; As well as related to the completeness and clarity of information before they choose the majors; The role of various parties in helping students choose the right majors in college.

The contradiction between the condition of the student with the goals and direction of the college, research conducted in 2016 [22] that describe the process of choosing majors, completeness and clarity of information before they choose the majors and the role of various parties, especially counselors in high school in helping students choose the right majors in college. As a follow up, the results of this research need to be discussed the role of various related parties (such as Academic Supervisors in university, Lecturers, and UPBK) in tackling the problem of incompatibility, the low interest of students so that the goals and direction of universities can be achieved.

\section{METHODS}

The data collection process is using DZ-MCI inventory (Daharnis Zadrian Majoring Choices Inventory) [1] which is complemented by the identification of respondents' data as a whole related to various aspects, such as culture, origins, choice of majors, study cost. This study involved the population of Universitas Negeri Padang students in 2016, with a sample of 428 people. Samples are scattered throughout the faculties and majors at Universitas Negeri Padang. Disclosure of election conditions majors, clarity and completeness of information using descriptive analysis [23], [24]. 


\section{RESULT}

Based on data collected from the study sample, the average level of student majors conformity with career aspirations was 74.73 (education student) and 74.46 in non-education students who feel fit between career aspirations with majors that they occupied

The findings indicate some of the possibilities that trigger a mismatch of career ideals with the majors that students currently occupy. One of these possibilities is presented in Table 1 .

Table 1. Elective Sequence of Majors Occupied by UNP Student in 2016 Based on Entrance Path

\begin{tabular}{|c|c|c|c|c|}
\hline \multirow{2}{*}{$\begin{array}{l}\text { Entrance } \\
\text { Path }\end{array}$} & \multicolumn{3}{|c|}{ Number of Selection } & \multirow{2}{*}{ Sum } \\
\hline & 1 & 2 & 3 & \\
\hline SNMPTN $^{\mathrm{a}}$ & $\begin{array}{ll} & 11 \\
0 & \end{array}$ & 64 & 13 & 187 \\
\hline SBMPTN $^{b}$ & 44 & 47 & 28 & 119 \\
\hline $\begin{array}{l}\text { Jalur } \\
\text { Mandiric }^{\mathrm{c}}\end{array}$ & 79 & 14 & 29 & 122 \\
\hline Sum & $\begin{array}{l}\quad 23 \\
3 \\
(54.44 \\
\%)\end{array}$ & $\begin{array}{r}125 \\
(29.21 \%)\end{array}$ & $\begin{array}{r}70 \\
(16.36 \%)\end{array}$ & $\begin{array}{r}428 \\
(100 \%)\end{array}$ \\
\hline
\end{tabular}

Exposure from Table 1 shows that many UNP students in the year of 2016 occupy a non-first choice $(45.57 \%)$. Even though the student made a choice in the current majors, it remains at the second and third entry points (i.e. SBMPTN and Jalur Mandiri). When viewed from the whole sample, only $104(24.30 \%)$ students pass on first choice and first choice. While the rest $(75.70 \%)$ of students pass on the second and third entrance. Moreover, there are students (6.78\%) who pass on the third option and on the third entrance path as well.

Some important things related to the variability of the student's choice are: First, the variability of choice and the path chosen is an indication of mismatch of departments occupied with career ideals, which in turn can affect students themselves specifically and to the institution in general [25]-[28]. Secondly, the students who pass on the first-track option as the first choice will basically not cause problems either for the students themselves or for the institution in general, but these needs to be examined again if the student chooses the department in order only to pass the test, with the consideration of majors that are quiet enthusiasts.

The mismatch conditions are also the effect of the parties who are determining the choice of students' majors. The role of the party who gives consideration even the prospective student in choosing the department will indicate how ready and suitable the students with the department to be occupied. These key actors are presented in Table 2.

Table 2. Descriptions of the Parties that Participating in the Election of Students' Majoring based on Rank

\begin{tabular}{|c|c|c|c|c|c|c|c|}
\hline \multirow{2}{*}{$\begin{array}{l}\text { Determi- } \\
\text { nants } \\
\text { Order }\end{array}$} & \multicolumn{7}{|c|}{ Determinants (\%) } \\
\hline & $\begin{array}{l}\text { The } \\
\text { student } \\
\text { itself } \\
\end{array}$ & Parents & Relatives & Counselor & $\begin{array}{l}\text { Tea- } \\
\text { chers }\end{array}$ & Friends & Others \\
\hline \multicolumn{8}{|c|}{ Educational Program } \\
\hline 1 & 69,82 & 18,18 & 3,27 & 2,91 & 2,91 & 1,45 & 1,45 \\
\hline 2 & 14,55 & $\mathbf{5 4 , 5 5}$ & 9,09 & 7,27 & 8,73 & 5,09 & 0,73 \\
\hline 3 & 6,55 & 11,27 & 35,27 & 17,82 & 16,00 & 12,36 & 0,73 \\
\hline 4 & 1,45 & 8,73 & 15,27 & 26,91 & 24,36 & 20,73 & 2,55 \\
\hline 5 & 2,91 & 3,64 & 20,73 & 22,18 & 24,36 & 23,27 & 2,91 \\
\hline 6 & 2,18 & 2,55 & 14,55 & 18,18 & 19,27 & 36,00 & 7,27 \\
\hline 7 & 2,55 & 1,09 & 1,82 & 4,73 & 4,36 & 1,09 & 84,36 \\
\hline \multicolumn{8}{|c|}{ Non-Educational Program } \\
\hline 1 & 76,40 & 16,85 & 2,25 & 2,25 & 1,12 & 1,12 & 0,00 \\
\hline 2 & 15,73 & 61,80 & 6,74 & 7,87 & 5,62 & 0,00 & 2,25 \\
\hline 3 & 4,49 & 8,99 & 39,33 & 13,48 & 17,98 & 13,48 & 2,25 \\
\hline 4 & 1,12 & 7,87 & 12,36 & 20,22 & 21,35 & 31,46 & 5,62 \\
\hline 5 & 0,00 & 4,49 & 17,98 & 31,46 & 24,72 & 17,98 & 3,37 \\
\hline 6 & 2,25 & 0,00 & 14,61 & 21,35 & 25,84 & 30,34 & 5,62 \\
\hline 7 & 0,00 & 0,00 & 6,74 & 3,37 & 3,37 & 5,62 & 80,9 \\
\hline
\end{tabular}

If analyzed from Table 2 on the Educational Programs students of Universitas Negeri Padang, it is seen that the students who choose the majors are quite varied. In this case, a total of $69.82 \%$ determines the choice of the current majors based on their own choice, while the remaining $(30.18 \%)$ as the second to the seventh determinant in the selection of majors currently occupied by other parties including; parents, relatives, counselor, teachers, friends and others. If viewed further, the other party is more dominant in determining the choice of student majors is the parent in addition to the student itself. The results are quite different shown by students who come from NonEducational Programs, i.e. as many as $76.40 \%$ who determine the choice in college is students itself. Although the next dominant determinants are also from parents, which quite different percentages from Educational Program. 
The condition of variation in selection of majors can be caused by various factors. These factors include; student/prospective student not yet independent in career decision making, culture and community views, and the lack of clarity of information regarding the majors/courses in university [29]-[34].

Related to the lack of clear information received, found the level of clarity and accuracy of information about the majors to be selected is 67.13. Thus, naturally there are students who feel not appropriate, want to move and regret to occupy their major. Unclear information can be caused by various factors, including information systems from one party, the concern of students and other related parties. Besides that, a "dangerous" thing is the deliberate falsehood of information provided by certain parties, so the prospective student feels "deceived" by the information. This issue will cause problems both for short and long term, especially on the students themselves.

These phenomena require an active role from a party that should play an important role in the selection process of the major, which is counselor. This study found the participation rate and the role of counselor is equal to 69.16 from ideal score. This means that the student assume that the counselor has not made an important role as it should be when they are in high school when selection majoring happens.

The condition of the problems encountered has an impact on the lack of management and learning process in universities, which in turn will make the achievement of national educational goals become difficult. For university, the difficulty of management is related to curriculum management, dissatisfaction toward university and academic achievement. While in the student condition it will have an impact on the delay of completion of study, low learning result, lack of motivation, low participation and Drop-Out [35][37]. In this case, Khan illustrates the connection between unsuitable majoring with the occurrence of Drop-Out [38], [39].

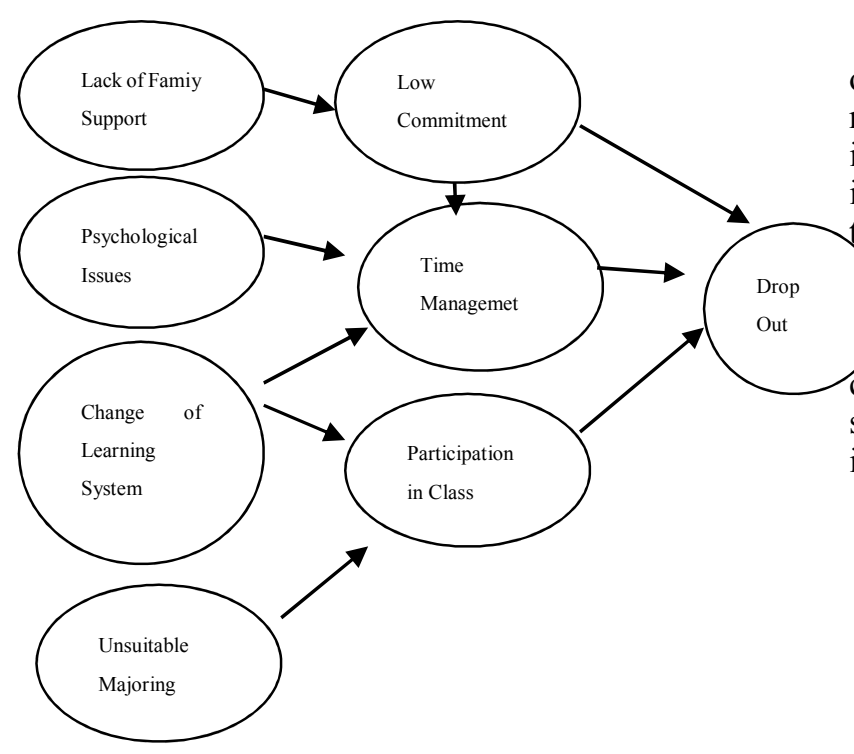

Fig 1. Linkage between miscellaneous majors, class participation and Drop-Out [38].

\section{DISCUSSION}

The condition of incompatibility of student career ideals with the major they occupy is the impact caused by many factors as described. Among the important factors is the clarity of information about the majors that will be selected by prospective students. To solve this problem, it is necessary to provide clear and complete information about the majors/programs at universities [1] either by the college or the school and other related parties. Of course, the concept of "promotion" in relation to "business" needs to be avoided to prospective students.

Responding to the issue of the order students majoring choices, there are need special attention from the institution and its entire staff. In addition for the future, the family, school and others need to provide assistance to prospective students in order to use "good" strategies in majoring selection [40], [41]. Therefore, if using a bad strategy there will be able to impact for the long term, especially on the students themselves. For example, they felt not appropriate between major/programs that occupied and regretfully when choose the major/program, which would ultimately impact on students and universities. For universities, if there are available opportunity to move majors/courses there would be disruptive, both administration and academic. For that reason, it seems necessary to have a special selection system in the admission for new students.

The position of the counselor role also needs to be optimized in many ways. The problem of mismatch may stem from the less role of counselor in providing information and providing services related to career ideals, interests, talents, and other supporting factors that exist in the students themselves. In order to yercome these problems, it needs the attention and role of various parties and prospective students emselves. For the future schools, especially counselors need to provide guidance and counseling services so the prospective students can independently make a selection majors/courses in 
college. The service can be providing to the students themselves and other parties who will "force" the students to choose the majors/ programs in universities [42]. This is done because in counseling the final decision is only on the client while the other party role is to provide and gave consideration (Prayitno, 2012; Depdiknas, 2007).

In accordance with the task and role counselor in schools, especially in relation to the field of career counseling [43], [44], counselor should truly run its role in guidance and counseling services. The types of services that can be done in carrying out its role are information services, placement and distribution, individual counseling, by applying the functions of counseling in schools, especially the function of selfunderstanding and college. It is intended to prospective students who choose the college have to match between his condition with the college environment (trait and factor) so that students would steady in their majors; and there is an appropriate condition between the majors that are occupied with the ideals of his career.

Strategies for optimizing the role of counselors in assisting students in choosing majors include visiting or early orientation to universities [45][1] or university parties visiting the school, so students would more familiar with the majors they will choose [46], [47], although these solutions requires a proper program and budgeting. The essential materials of the information are (1) universities name (2) the accreditation of universities, (3) the accreditation of the department, (4) the campus address, (5) the faculty, (6) (9) tuition fees, (10) other expenses, (11) campus facilities, (12) campus atmosphere and environment, (13) scholarships, (14) staffs, (15) career prospects [1]. These are based on the findings that the information provided by counselors is incomplete in helping students to set their majors options. In addition, there is needs the cooperation between counselors with related parties in terms of providing this information, so that students can choose a major that matches with their interests and ideals of his career. The active role of counselor in carrying out these services is urgently needed [20].

In universities, the services for students who experience incompatibility with their majors that they occupy required an active role from various parties, which are: a counselor in universities, major's chief and academic supervisors [48]-[50]. The direction of the service at the college includes the optimization of in-depth/complete understanding of majors, repositioning/ moving majors [1], in which case of the student's case characteristics are adjusted.

\section{REFERENCES}

Daharnis and Z. Ardi, "Sistem Rekrutmen, Orientasi dan Penempatan Mahasiswa," in Konvensi Nasional Pendidikan Indonesia (KONASPI) VIII Tahujn 2016, 2016, pp. 144-148.

Kementerian Pendidikan dan Kebudayaan, Undang-undang nomor 12 tahun 2012 tentang Pendidikan Tinggi. 2012.

Presiden Republik Indonesia, "Peraturan Presiden Republik Indonesia No. 8 tahun 2012 tentang Kerangka Kualifikasi Nasional Indonesia," Pres. Republik Indones., 2012.

Kemenristekdikti, "Rencana Strategis
Kementerian Riset, Teknologi dan
Pendidikan Tinggi Tahun 2015-2019."
Jakarta: Kemenristek Dikti RI, 2015.

Prayitno dkk, Keterampilan Belajar. Jakarta: Depdikbud, 1997.

] Daharnis, Erlamsyah, Ifdil, Z. Ardi, and R. Hariko, "Gambaran Kegiatan Belajar Siswa Sumatera Barat," in Seminar Internasional Bimbingan dan Konseling, 2014.

] F. M. Kutty, "Mapping their road to university: First-generation students' choice and decision of university," Int. Educ. Stud., vol. 7, no. 13, pp. 49-60, 2014.

B. Sojkin, P. Bartkowiak, and A. Skuza, "Changes in students ' choice determinants in Poland :," High Educ, pp. 209-224, 2015.

] J. Nyamwange, "Influence of Student' $\mathrm{s}$ Interest on Career Choice among First Year University Students in Public and Private Universities in Kisii County, Kenya," $J$. Educ. Pract., vol. 7, no. 4, pp. 96-102, 2016.

] J. Kim and Y. Hwang, "The Effects of School Choice on Parental School Participation and School Satisfaction in Korea," Soc Indic Res, pp. 363-385, 2014.

Daharnis, Erlamsyah, Alizamar, and Ifdil, "Analisis Hasil Belajar Mahasiswa Jurusan Bimbingan dan Konseling FIP UNP Ditinjau dari Mutu Kegiatan Belajar, Angkatan, status Masuk dan jenis Kelamin," Universitas Negeri Padang, 2011.

Erlamsyah, Daharnis, Afdal, Ifdil, and Z. Ardi, "Hubungan Aspirasi, Persepsi, Locus of Control, Angkatan dan Status Masuk dengan Kegiatan Belajar Mahasiswa Jurusan 
Bimbingan dan Konseling FIP UNP," Universitas Negeri Padang, 2011.

[13] S. . Elliot, T. . Kratochwill, J. . Littlefield, and J. . Travers, Educational Psychology. Madison: Brown \& Benchmark, 1996.

[14] S. Klein and S. Washburn, "A Case Study of the Search Phase of College Choice as Experienced Prospective Students Visiting a Midwest College of Agriculture," NACTA J., no. December, 2012.

[15] I. Pablo-lerchundi, M.-C. Núñez-del-Río, and R.-M. González-Tirados, "Career choice in engineering students: its relationship with motivation, satisfaction and the development of professional plans," An. Psicol., vol. 31, pp. 268-279, 2015.

[16] N. Tereza, "Analysis and Comparison of Factors Influencing University Choice," $J$. Compet., vol. 5, no. 3, pp. 90-100, 2013.

[17] S. Mupemhi, "Factors influencing choice of a university by students in Zimbabwe," African J. Bus. Manag., vol. 7, no. 36, pp. 3723-3729, 2013.

[18] C. Albert and C. Garc1'a-Serrano, "Cleaning the slate? School choice and educational outcomes in Spain," High Educ, pp. 559-582, 2010.

[19] C. Timothy, "Who And What Influences Choice Of University? Student And University Perceptions," Am. J. Bus. Educ., vol. 3 , no. 10, p. 9, 2010.

[20] D. Daharnis and Z. Ardi, "THE COMPATIBILITY STUDENT CHOICE OF UNIVERSITY MAJORING; A PRELIMINARY STUDIES," Guid. J. Guid. Couns. Psychol. Educ., vol. 6, no. 1, pp. 101109, 2016.

[21] Z. Ardi and F. M. Yendi, "Konseling Online: Sebuah Pendekatan Teknologi Dalam Pelayanan Konseling," J. Konseling dan Pendidik., vol. 1, no. 1, pp. 1-5, 2013.

[22] Daharnis and Z. Ardi, "Pemilihan Jurusan oleh Mahasiswa UNP Angkatan 2016 dan Peranan Guru BK/Konselor di SLTA," Padang, 2016.

[23] M. G. Lodico, Methods In Educational Research:from Theory to Practice. San Francisco: Wiley Imprint, 2006.

[24] K. Singh, Quantitative Social Research Methods. Singapore: Sage Publications Asia-
Pasific, 2007.

[25] R. Hos and M. Kekec, "The mismatch between non-native English as a foreign language (EFL) teachers' grammar beliefs and classroom practices," J. Lang. Teach. Res., vol. 5, no. 1, pp. 80-87, 2014.

[26] P. Cappelli, "Skill gaps, skill shortages and skill mismatches: evidence for the US," National Bureau of Economic Research, 2014 .

[27] M. Luppino and R. Sander, "College major peer effects and attrition from the sciences," IZA J. Labor Econ., vol. 4, no. 1, p. 4, 2015.

[28] P. Arcidiacono, E. M. Aucejo, H. Fang, and K. I. Spenner, "Does affirmative action lead to mismatch? A new test and evidence," Quant. Econom., vol. 2, no. 3, pp. 303-333, 2011

[29] J. Zhu, S. Rodgers, and K. M. Melia, "The impact of safety and quality of health care on Chinese nursing career decision-making," $J$. Nurs. Manag., vol. 22, no. 4, pp. 423-432, 2014.

[30] P. R. J. M. Garcia, S. L. D. Restubog, P. Bordia, S. Bordia, and R. E. O. Roxas, "Career optimism: The roles of contextual support and career decision-making selfefficacy," J. Vocat. Behav., vol. 88, pp. 10 $18,2015$.

[31] Z. Jiang, "Emotional Intelligence and Career Decision-Making Self-Efficacy: National and Gender Differences," J. Employ. Couns., vol. 51, no. 3, pp. 112-124, 2014.

[32] H. T. Holmegaard, L. M. Madsen, and L. Ulriksen, "To choose or not to choose science: Constructions of desirable identities among young people considering a STEM higher education programme," Int. J. Sci. Educ., vol. 36, no. 2, pp. 186-215, 2014.

[33] J. R. Abel and R. Deitz, "Do the benefits of college still outweigh the costs?," 2014.

[34] M. Wiswall and B. Zafar, "How do college students respond to public information about earnings?," J. Hum. Cap., vol. 9, no. 2, pp. 117-169, 2015.

[35] P. Amartayakul, "FACTORS AFFECTING GRADUATE STUDENTS ' DECISIONS TO DROP," Int. J. Arts Sci., vol. 7, no. 2, pp. 557-566, 2014.

[36] S. Paik and W. Shim, "Tracking and College 
Major Choices in Academic High Schools in South Korea," Asia-Pacific Edu Res, vol. 22, pp. 389-397, 2013.

[37] T. D. Hoisch and J. I. Bowie, "Assessing Factors that Influence the Recruitment of Majors from ...," J. Geosci. Educ., vol. 58, no. 3, 2010 .

[38] Y. A. Khan, Z. Ahamad, and S. Kousar, "Factors Influencing Academic Performance of University Students," Int. J. Educ. Adm. Policy Stud., vol. 5, no. November, pp. 7984, 2015.

[39] F. Belloc, A. Maruotti, and L. Petrella, "University drop-out : an Italian experience," High Educ, no. November 2009, pp. 127$138,2010$.

[40] N. A. C. Román and E. T. Hamann, "College dreams à la Mexicana... agency and strategy among American-Mexican transnational students," Lat. Stud., vol. 12, no. 2, pp. 237258, 2014.

[41] W. Barnes and J. R. Slate, "College-readiness rates in Texas: A statewide, multiyear study of ethnic differences," Educ. Urban Soc., vol. 46, no. 1, pp. 59-87, 2014.

[42] Daharnis, "Peminatan Peserta Didik: Ketidakcocokan Minat dengan Kondisi Peserta Didik, Orangtua dan Sekolah serta Upaya Penanggulangannya," in International Guidance and Counseling Seminar 2014, 2014.

[43] Prayitno, Jenis Layanan dan Kegiatan Pendukung Konseling. Padang: Universitas Negeri Padang, 2012.

[44] S. . Gladding, Konseling: Profesi Menyeluruh (alih Bahasa oleh Winarno dan Lilian Yuwono). Jakarta, 2009.

[45] M. G. Kopp, “Academic libraries , institutional missions, and new student recruitment : a case study," Ref. Serv. Rev., 2008.

[46] S. Mirzaeei, M. Rezaei, and S. Roshankhah, 'Pharmacy Students' Satisfaction Rate with their Majors and its Relationship with Educational Status in Kermanshah University of Medical Sciences (2014)," Educ. Res. Med. Sci. J., vol. 5, no. 2, pp. 81-86, 2016.

[47] L. Ding, X. Wei, and X. Liu, "Variations in university students' scientific reasoning skills across majors, years, and types of institutions," Res. Sci. Educ., vol. 46, no. 5, pp. 613-632, 2016.

[48] G. Wichmann-Hansen, R. Thomsen, and H. M. Nordentoft, "Challenges in collective academic supervision: Supervisors' experiences from a Master Programme in Guidance and Counselling," High. Educ., vol. 70, no. 1, pp. 19-33, 2015.

[49] L. D. Borders et al., "Best practices in clinical supervision: Evolution of a counseling specialty," Clin. Superv., vol. 33, no. 1, pp. 26-44, 2014.

[50] H. E. McEwan and D. Tod, "Learning experiences contributing to service-delivery competence in applied psychologists: Lessons for sport psychologists," J. Appl. Sport Psychol., vol. 27, no. 1, pp. 79-93, 2015. 